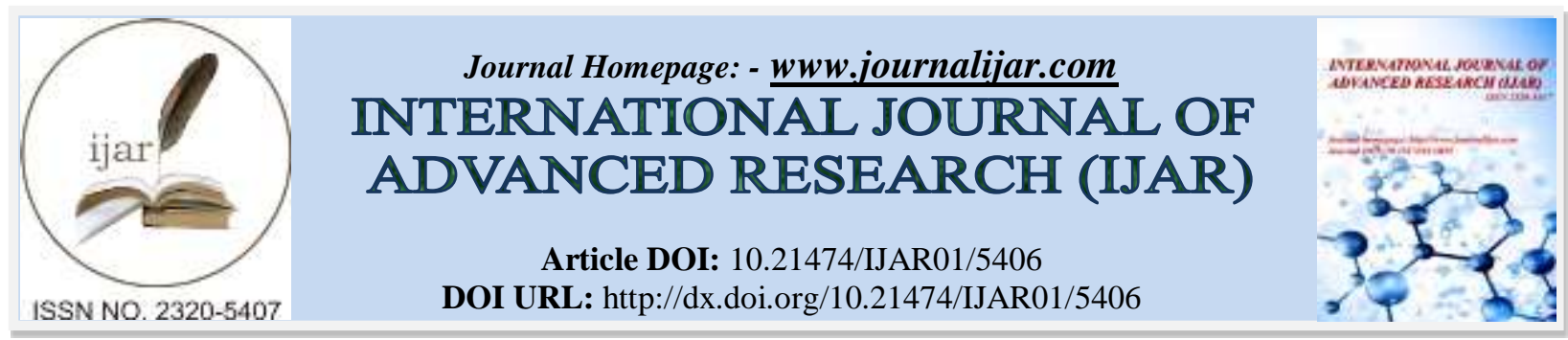

RESEARCH ARTICLE

\title{
NON PERFORMING ASSETS- A REVIEW ON THE PROBLEMS AND SOLUTION TAKEN BY BANKS IN INDIA.
}

P. Arul Moli M.Com., M.Phil.

Asst.Professor, Department of Commerce CA, AJK College of Arts and Science, Coimbatore.

\section{Manuscript Info}

Manuscript History

Received: 12 July 2017

Final Accepted: 14 August 2017

Published: September 2017

Key words:-

Bank, NPA, RBI.

\begin{abstract}
Banking sector is one of the most important sectors across the globe for the growth and development of any country. Banking sector must remain healthy and work efficiently so as to meet the demands of the industry as well as consumers. NPAs are any asset of a bank which is incapable of producing any returns. Non Performing Assets are the major problem for the public sector and private sector banks in India. The present study focuses on analyzing the problems and solutions taken for managing and controlling the NPA in both private and public sector banks which help to improve the financial health of the banking sector in India. The study is based on the secondary data retrieved from various reports, journals and from RBI website.
\end{abstract}

Copy Right, IJAR, 2017,. All rights reserved.

\section{Introduction:-}

All advances given by banks are termed as "assets", as they generate income for the bank by way of interest or instalments.However, a loan turns bad if the interest or instalment remains unpaid even after the due date and turns into a non performing asset or NPA.

The concept of NPA is introduced by RBI to reflect a banks actual financial health in its balance sheet and as per the recommendations made by the Narasimham Committee report I and II to address the credit monitoring process being adopted and pursued by the banks and financial institutions. To strengthen further the recovery of dues by banks and financial institutions, Government of India promulgated The Recovery of Debts Due to Banks and Financial Institutions Act, 1993 and The Securitisation and Reconstruction of Financial Assets and Enforcement of Security Interest Act, 2002.

A Non-performing asset is defined as a credit facility in respect of which the interest or instalment of principal has remained' past due' for a specified period of time. It results from what are termed as "Bad loans" or defaults. It is the failure to meet financial obligations, say non-payment of a loan instalment. Once the borrower has failed to make interest or principle payments for 90 days the loan is considered to be a non-performing asset. Non-performing assets are difficult for financial institutions since they depend on interest payments for income. Accordingly, with effect from March 31, 2004, a non-performing asset (NPA) is a loan or an advance where:

- Interest and/or installment of principal remain overdue for a period of more than 91 days in respect of a term loan,

- The account remains 'out of order' for a period of more than 90 days, in respect of an Overdraft/Cash Credit,

- The bill remains overdue for a period of more than 90 days in the case of bills purchased and discounted,

Corresponding Author:- P. Arul Moli .

Address:- Asst.Professor, Department of Commerce CA, AJK College of Arts and Science, 
- Interest and/or installment of principal remains overdue for two harvest seasons but for a period not exceeding two half years in the case of an advance granted for agricultural purposes, and

- Any amount to be received remains overdue for a period of more than 90 days in respect of other accounts.

- Non submission of Stock Statements for 3 Continuous Quarters in case of Cash Credit Facility.

- No active transactions in the account( Cash Credit/Overdraft/EPC/PCFC) for more than 91 days

\section{Classification of NPA:-}

The non-performing assets can be further classified into four categories based on the period for which the asset has remained non-performing and the realisability of the dues:

1. Standard assets: a standard assets are those which do not disclose any problems and which do not carry more than normal risk attached to the business. Such assets are not NPA.

2. Sub-standard assets: a sub standard asset is one which has been classified as NPA for a period not exceeding 12 months.

3. Doubtful Assets: a doubtful asset is one which has remained NPA for a period exceeding 18 months. In the case of term loans, those where installments of principal have remained overdue for a period exceeding 18 months should be treated as doubtful.

4. Loss assets: where loss has been identified by the bank, internal or external auditor or central bank inspectors. But the amount has not been written off, wholly or partly. Such assets are considered uncollectable and of such little values that their continuance as bank assets in not warranted although there may be some salvage or recovery values.

Causes of NPA:-

The following are some of the major causes of NPA:

- Speculation: Investing in high risk assets to earn high income.

- Default: One of the main reasons behind NPA is default by borrowers.

- Economic conditions: The Economic condition of a region affected by natural calamities or any other reason may cause NPA.

- No more proper risk management: Sometimes banks provide loans to borrowers with bad credit history. There are high probabilities of default in these cases.

- Mis-management: Often ill minded borrowers bribe bank officials to get loans with an intention of default.

- Diversion of funds: Many times borrowers divert the borrowed funds to purposes other than mentioned in loan documents. It is very hard to recover from this kind of borrowers.

- Internal factors: Many internal factors like defective lending process, inappropriate technology, improper SWOT analysis, poor credit appraisal system, managerial deficiencies, absence of regular industrial visits etc.

- External factors: Many external factors like ineffective recovery tribunal, willful defaults, natural calamities, industrial sickness, lack of demand, change on govt policies etc.

\section{Impact of NPA:-}

NPAs do not just reflect badly in a bank's account books, they adversely impact the national economy. Following are some of the repercussions of NPAs:

- Depositors do not get rightful returns and many times may lose uninsured deposits. Banks may begin charging higher interest rates on some products to compensate Non-performing loan losses

- Bank shareholders are adversely affected

- Bad loans imply redirecting of funds from good projects to bad ones. Hence, the economy suffers due to loss of good projects and failure of bad investments.

- When bank do not get loan repayment or interest payments, liquidity problems may ensue.

\section{Measures to solve problems of NPA:-}

The Narasimham Committee has recommended a number of steps to reduce NPA. The following are the steps taken to control NPA:

- Debt Recovery Tribunals: Narasimham Committee Report I recommended the setting up of special Tribunals to reduce the time required for setting cases.

- Seciritisation Act 2002: Securitisation and Reconstruction of Financial Assets and Enforcement of Security Interest act 2002 is popularly known as Securitisation Act. This act enables the banks to issue notice to defaulters who have to pay the debts within 60 days. 
- Lok Adalats: Lok Adalats have been found suitable for the recovery of small loans.

- Compromise Settlement: Compromise Settlement Scheme provides a simple mechanism for recovery of NPA.

- Credit Information Bureau: A good information system is required to prevent loans from turning into a NPA. If a borrower is a defaulter to one bank this information should be available to all banks so that they may avoid lending to him.

Steps taken by RBI to control NPA: In recent years RBI and Government has undergone many steps to control the NPA in India:

- Government has launched 'Mission Indradhanush' to make the working of public sector bank more transparent and professional in order to curb the menace of NPA in future.

- Government has also proposed to introduce Bankruptcy code.

- RBI introduced number of measures in last few years which include tightening the Corporate Debt Restructuring (CDR) mechanism, setting up a Joint Lenders' Forum, prodding banks to disclose the real picture of bad loans, asking them to increase provisioning for stressed assets, introducing a 5:25 scheme where loans are to be amortized over 25 years with refinancing option after every 5 years, and empowering them to take majority control in defaulting companies under the Strategic Debt Restructuring (SDR) scheme.

\section{Review of Literature:-}

Many journals and articles have been published under non performing assets on Indian banking industry. A review of the relevant literature has been described.

1. Vivek Rajbahadur Singh (2016), this paper has made an attempt to understand NPA, the status and trend of NPAs in Indian Scheduled commercial banks, The factors contributing to NPAs, reasons for high impact of NPAs on Scheduled commercial banks in India and recovery of NPAS through various channels.

2. Sulagna Das , AbhijitDutta, (2014), the current paper with the help of secondary data, from RBI website, tried to analyse the 6 years, (2008-2013) net non-performing asset data of 26 public sector banks, by using Annova statistics, and with the help of SPSS software. The main objective of the study is to find out if there are any significant differences in the mean variation of the concerned banks. This paper also focuses on the reason behind the NPA and its impact on banking operations.

3. Srinivas K T (2013), present paper is undertaken to study the reasons for advances becoming NPA in the Indian Commercial banks Sector and to give suitable suggestion to overcome the mentioned problem. The present study of Non-performing assets is confined and restricted to the boundary of commercial banks and data is analyzed since1996-97 up to 2011-12. Data is gathered from the secondary sources to achieve the aforesaid objectives. Secondary data: secondary RBI bulletins, research papers etc. The data collected from the secondary sources relating to NPAs has been analyzed and tabulated and drawn the appropriate tables. Interpretations were made based on table

\section{Objectives of the study:-}

- To know the concept of NPA in detail.

- To understand the major impact of NPA.

- To analyse the problems and measures taken by banks to control the NPA in India.

- To study the comparison between gross NPA and net NPA of selected public sector and private sector banks in India.

\section{Research Methodology:-}

The present study uses secondary data available in the websites, articles, journals, magazines, newspaper, periodicals and papers relating to NPA published were collected and the data available on internet and other source has also been used. The scope of the data has been limited to five years from 2013 to 2017.The banks selected for the study includes:

- Public sector banks: SBI, Bank of Baroda, Punjab National Bank \& Central Bank of India

- Private sector banks: HDFC Bank, Axis Bank, Kotak Mahindra and Indusind Bank.

\section{Difference between Gross NPA and Net NPA:-}

Gross NPA is the sum of all loan assets that are classified as NPA as per RBI guidelines. Gross NPA ratio is the ratio of gross NPA to gross advances (loans) of the bank.NPA is simply the total bad assets (actual) minus the provision left aside. If the banks need to be healthy the Net NPA must be close to zero. If an individual bank has net NPA in negative, then that is a good sign. 
- $\quad$ Net non performing assets $=$ Gross NPAs - Provisions

Data Analysis of Gross NPA and Net NPA:-

Here are some of the banks selected from public sector and private sector to analyse the highest and lowest percentage of gross NPA and net NPA in India.

Table 1:- Gross NPA of Public sector banks in India

\begin{tabular}{|l|l|l|l|l|}
\hline Month/Year & State bank of India & Punjab National bank & Central bank of India & Bank of Baroda \\
\hline Mar 2013 & 4.75 & 4.27 & 4.80 & 2.40 \\
\hline Mar 2014 & 4.95 & 5.25 & 6.27 & 2.94 \\
\hline Mar 2015 & 4.25 & 6.55 & 6.09 & 3.72 \\
\hline Mar 2016 & 6.50 & 12.90 & 11.95 & 9.99 \\
\hline Mar 2017 & 6.90 & 12.53 & 17.81 & 10.46 \\
\hline Average & 5.47 & $\mathbf{8 . 3}$ & $\mathbf{9 . 3 8}$ & $\mathbf{5 . 9 0}$ \\
\hline
\end{tabular}

Table 2:- Net NPA of Public sector banks in India

\begin{tabular}{|l|l|l|l|l|}
\hline Month/Year & State bank of India & Punjab National bank & Central bank of India & Bank of Baroda \\
\hline Mar 2013 & 2.10 & 2.35 & 2.90 & 1.28 \\
\hline Mar 2014 & 2.57 & 2.85 & 3.75 & 1.52 \\
\hline Mar 2015 & 2.12 & 4.06 & 3.61 & 1.89 \\
\hline Mar 2016 & 3.81 & 8.61 & 7.36 & 5.06 \\
\hline Mar 2017 & 3.71 & 7.81 & 10.20 & 4.72 \\
\hline Average & 2.86 & 2.46 & 5.56 & 2.89 \\
\hline
\end{tabular}

From the above Table $1 \& 2$ it is clearly understood that the highest average gross NPA and net NPA is found in Central bank of India at $9.38 \%$ and $5.56 \%$ and also the lowest average gross NPA is found in State bank of India at $5.47 \%$ and net NPA is found in Punjab National bank at 2.465.From the above observations the performance of SBI and PNB is better than CBI.

Table 3:- Gross NPA of Private sector banks in India

\begin{tabular}{|l|l|l|l|l|}
\hline Month/Year & HDFC bank & Axis bank & Indusind bank & Kotak Mahindra bank \\
\hline Mar 2013 & $\mathbf{0 . 9 7}$ & $\mathbf{1 . 0 6}$ & 1.03 & 1.55 \\
\hline Mar 2014 & 1.00 & 1.22 & 1.12 & 1.98 \\
\hline Mar 2015 & $\mathbf{0 . 9 0}$ & 1.34 & 0.81 & 1.85 \\
\hline Mar 2016 & $\mathbf{0 . 9 4}$ & 1.67 & 0.87 & 2.36 \\
\hline Mar 2017 & 1.05 & 5.04 & 0.93 & 2.59 \\
\hline Average & 0.97 & 2.07 & 0.95 & 2.07 \\
\hline
\end{tabular}

Table 4:- Net NPA of Private sector banks in India

\begin{tabular}{|l|l|l|l|l|}
\hline Month/Year & HDFC bank & Axis bank & Indusind bank & Kotak Mahindra bank \\
\hline Mar 2013 & 0.20 & 0.32 & 0.31 & 0.64 \\
\hline Mar 2014 & 0.30 & 0.40 & 0.33 & 1.08 \\
\hline Mar 2015 & 0.20 & 0.44 & 0.31 & 0.92 \\
\hline Mar 2016 & 0.28 & 0.70 & 0.39 & 1.06 \\
\hline Mar 2017 & 0.33 & 2.11 & 0.39 & 1.26 \\
\hline Average & 0.26 & 0.79 & 0.35 & 0.99 \\
\hline
\end{tabular}

From the above Table $3 \& 4$ it is clearly observed that the highest average gross NPA is found in Axis bank and Kotak Mahindra bank at 2.07\% and Highest net NPA in Kotak Mahindra bank at $0.99 \%$ and also the lowest average gross NPA is found in Indusind bank at $0.95 \%$ and lowest net NPA in HDFC bank at $0.26 \%$.It is also observed from the above data that the performance of HDFC bank and Indusind bank is comparatively better than the Axis and Kotak Mahindra bank. It is understood from the information that all the selected private sector and public sector banks during the period of study from 2013 to 2017 is found that the net NPA is increasing year by year. 
According to a baseline scenario projection by the Reserve Bank of India (RBI) in its Financial Stability Report it is said that Gross bad loans at commercial banks could increase to 8.5 per cent of total advances by March 2017, from 7.6 per cent in March 2016. "The macro stress test suggests that under the baseline scenario, the gross NPA may rise to 8.5 per cent by March 2017," the and "if the macro situation deteriorates in the future, the gross NPA ratio may increase further to 9.3 per cent by March 2017."The rise in gross NPA is mainly because of the AQR (Asset Quality Review).The AQR conducted by the banking regulator found several restructured advances, which were standard in the bank's books that needed to be reclassified as nonperforming. The net NPA of the private sector banks also increased sharply to 4.6 percent in March 2016, from 2.8 percent in September 2015.Public sector banks net NPA was 6.4 percent, while the ratio for private sector banks was 4.6 percent. On the business side it is noted that the credit and deposit growth remained in single digits for the previous financial year. While credit growth was 8.8 percent, deposit growth was 8.1 percent. There was a stark difference in the credit and deposit growth of public sector banks as compared with their private sector banks. According to RBI data for public sector banks, loan grew at 4 percent while it was 24.6 percent for private banks. Deposits of public banks grew by 5.2 percent, while for private banks it was 17.3 percent.

\section{Conclusion:-}

From the entire study it is observed that the percentage of net NPA of private sector banks are comparatively less when compared with public sector banks. If the banks need to be healthy the net NPA must be close to zero. The NPAs play a major role in the balance sheet of a bank. Hence the banker should follow the rules framed and strictly monitor the operations of the banks. And the banks must take necessary measures to improve the management of non performing assets of both public sector and private sector banks in India. The RBI which is the apex body should even more pressurize the banks to monitor the activities on lending money which will result in reducing of NPAs in future.

\section{Reference:-}

1. Vivek Rajbahadur Singh," A Study of Non-Performing Assets of Commercial Banks and it's recovery in India", Annual Research Journal of SCMS, Pune, Vol. 4, March 2016 ISSN 2348-0661.

2. Sulagna Das, AbhijitDutta," A Study on NPA of Public Sector Banks in India", IOSR Journal of Business and Management (IOSR-JBM) e-ISSN: 2278-487X, p-ISSN: 2319-7668. Volume 16, Issue 11.Ver. I (Nov. 2014), PP 75-83 www.iosrjournals.org.

3. Pacha Malyadri, S. Sirisha," A Comparative Study of Non Performing Assets in Indian Banking Industry", International Journal of Economic Practices and Theories, Vol. 1, No. 2, 2011 (October), e-ISSN 2247 - 7225.

4. Ibha Rani," A Study of Non Performing Assets (NPA) Management in Indian Banking”, Sai Om Journal of Commerce \& Management, Volume 3, Issue 4 (April, 2016) Online ISSN-2347-7563.

5. Vaibhavi Shah, Sunil Sharma," A COMPARATIVE STUDY OF NPA IN ICICI BANK AND HDFC BANK", Abhinav National Monthly Refereed Journal of Research in Commerce \& Management, Volume 5, Issue 2 (February, 2016) Online ISSN-2277-1166.

6. Srinivas K T," A Study On Non- Performing Assets Of Commercial Banks In India", International Monthly Refereed Journal of Research In Management \& Technology, Volume II, December'13 ISSN - 2320-0073.

7. http://www.iasscore.in/special-details-34.html.

8. http://www.caclubindia.com/articles/npa-non-performing-assets-15399.asp.

9. http://www.moneycontrol.com/financials/statebankindia/results/yearly/SBI

10. http://www.moneycontrol.com/financials/punjabnationalbank/results/yearly/PNB05

11. http://www.moneycontrol.com/financials/centralbankindia/results/quarterly-results/CBO01

12. http://www.moneycontrol.com/financials/bankofbaroda/results/quarterly-results/BOB

13. http://www.moneycontrol.com/financials/hdfcbank/results/quarterly-results/HDF01

14. http://www.moneycontrol.com/financials/axisbank/results/quarterly-results/AB16

15. http://www.moneycontrol.com/financials/indusindbank/results/quarterly-results/IIB

16. http://www.moneycontrol.com/financials/kotakmahindrabank/results/quarterly-results/KMB 